\title{
Integrated effects of the Deepwater Horizon oil spill on nearshore ecosystems
}

\author{
Mary C. Baker ${ }^{1, *}$, Marla A. Steinhoff ${ }^{1}$, Gail F. Fricano ${ }^{2}$ \\ ${ }^{1}$ NOAA Office of Response and Restoration, 7600 Sand Point Way NE, Seattle, WA 98115, USA \\ ${ }^{2}$ Industrial Economics, Inc., 2067 Massachusetts Ave., Cambridge, MA 02140, USA
}

\begin{abstract}
The interconnected nearshore habitats of the northern Gulf of Mexico provide refuge and feeding opportunities for fish and wildlife, including open water, shoreline, and terrestrial species. The Deepwater Horizon oil spill natural resource damage assessment documented injury as a result of the oiling of over $2113 \mathrm{~km}$ (1300 miles) of shoreline over an $87 \mathrm{~d}$ release from the wellhead. Field and laboratory studies indicate that oil degraded the health of coastal marsh vegetation and associated fauna, resulted in the loss of nearshore oyster cover, and increased erosion of oiled marsh edge habitat over approximately $174 \mathrm{~km}$ (108 miles) of shoreline. Sand beach habitat, submersed aquatic vegetation, and subtidal oysters were injured by a combination of oiling and response actions. The loss of billions of oysters resulted in failed recruitment over several years in the most severely affected areas (Barataria Bay, Black Bay/Breton Sound, and Mississippi Sound). Affected ecosystem services include supporting services (e.g. primary production) and provisioning services (e.g. fish and invertebrate abundance). Loss of vegetation and nearshore oysters and increased shoreline erosion may have disrupted regulating services associated with stable marsh (e.g. coastal storm and flood protection). The loss of marsh vegetation and oysters likely reduced nutrient cycling and water filtration services. Recovery of natural resources may take more than $20 \mathrm{yr}$ in some areas. To prepare for future spills, we recommend that natural resource trustees develop generic conceptual models and prepare integrated injury assessment approaches for nearshore habitats to facilitate future injury quantification. Additional exploration of the trade-offs between response options could minimize or shift natural resource injury for future spills.
\end{abstract}

KEY WORDS: Mobile drilling unit - Natural resource damage assessment - NRDA - Salt marsh · Nearshore $\cdot$ Oyster $\cdot$ Aquatic vegetation

\section{INTRODUCTION}

The 20 April 2010 explosion, subsequent fire, and sinking of the Deepwater Horizon (DWH) mobile drilling unit triggered a massive release of oil from BP's Macondo well. Initial efforts to cap the well were unsuccessful, and the well continuously released oil into the northern Gulf of Mexico for $87 \mathrm{~d}$ after the explosion. Oil from this release first approached nearshore areas in May 2010.

The Gulf Coast contains some of the world's most biologically diverse and interconnected habitats, in-

${ }^{*}$ Corresponding author: mary.baker@noaa.gov

${ }^{\S}$ Advance View was available online December 14, 2016 cluding coastal salt marshes, mangroves, estuaries, sand beaches, dunes, submersed aquatic vegetation (SAV), and barrier islands. These nearshore habitats form a complex mosaic of structural refuge and foraging habitat for fish, invertebrates, terrestrial animals, and migratory birds. The assessment of injuries from the DWH spill focused on the health of these habitats to meet the requirements of the Oil Pollution Act of 1990 (OPA) regulations on natural resource damage assessment (NRDA). Indicators of injury were selected for each nearshore habitat type, with greater emphasis on habitats that received the great-

() G. F. Fricano and outside the USA, the US Government 2017. Open Access under Creative Commons by Attribution Licence. Use, distribution and reproduction are unrestricted. Authors and original publication must be credited. Publisher: Inter-Research - www.int-res.com 
est extent and magnitude of oiling (e.g. marsh surface and edge communities).

NRDA is a legal process to determine injuries to public natural resources following oil spills or the release of hazardous substances, and to plan and implement an approach for restoring those resources. The goal of an NRDA is to assess the severity and duration of injury to natural resources and determine appropriate restoration of the injured environment. Trustee entities (federal, state, or tribal) must document connections between the release of, pathways for, and exposure to oil or hazardous substances (and response actions taken to respond to the spill); and the extent, magnitude, and duration of injuries. Injury quantification entails determining the degree, and spatial and temporal extent, of injuries relative to the condition the natural resources would have been in had the oil spill not occurred (i.e. baseline). Oil can injure natural resources through toxicity and physical smothering. Response actions such as removing contaminated sand or oiled wrack, flushing or raking marsh shorelines, or releasing river water in an attempt to keep oil from stranding can also injure habitats and natural resources, and responsible parties are liable for these injuries. Restoration is intended to compensate the public for lost services provided by natural resources and return the injured resources to baseline conditions. To determine baseline conditions, trustees use information on conditions before the spill, trends over time, and/or data from appropriate reference sites.

Natural resource trustee agencies for the DWH NRDA include the US Department of Commerce (NOAA), US Department of the Interior, US Environmental Protection Agency, US Department of Agriculture, and the states of Alabama, Florida, Louisiana, Mississippi, and Texas. Trustee agencies vary according to the natural resources affected by a particular spill. Trustee responsibilities include assessing injuries to natural resources, negotiating settlements with responsible parties, and implementing or overseeing restoration actions to compensate for injury.

The objectives of this synthesis are to integrate the findings of the DWH NRDA injury studies for nearshore habitats and to present considerations for future oil spill injury assessments. First, the assessment approach for the DWH NRDA will be discussed, followed by a summary of injury findings. These efforts have informed considerations for future spills, which will be presented last. In order to assess community- and ecosystem-level injuries, future assessments should evaluate multiple injury indicators at the same locations and extend them to other areas based on exposure conditions (e.g. polycyclic aromatic hydrocarbon [PAH] concentrations and shoreline oiling extent and magnitude).

\section{ASSESSMENT APPROACH}

For the DWH NRDA, the trustees developed a series of interconnected conceptual models for coastal wetlands, oyster reef, beach, and SAV nearshore habitats affected by the spill and response actions (see Figs. $1 \& 2$ as examples). Because of the large geographic and temporal scale of the spill and the numerous habitats and species potentially injured, the environment was divided into habitat and species groups to plan and implement assessment activities. Findings from nearshore habitats were then interpreted together to consider the integrated effects of shoreline and sediment oiling, while nearshore water column injury was integrated with the assessment of offshore water column injury. Injuries to birds, marine mammals, and sea turtles were evaluated through independent assessment activities. Findings from water column, nearshore bird, coastal dolphin, and nesting sea turtle studies will be briefly described here as additional indicators of ecosystem-scale injury.

In developing a pathway model to support study designs (Fig. 2), the trustees applied criteria based on requirements of the OPA NRDA regulations to identify representative species that may have been exposed and injured. Criteria for selecting species included representation of multiple trophic levels and the potential ability to detect adverse change from baseline conditions, to quantify and scale injuries, and to identify restoration projects that could compensate for injuries. Based on experience with other NRDAs, injuries indicated by measurements with high natural variability (e.g. community metrics and many indicators of microbial processes) are difficult to relate to contaminant exposures, and were therefore excluded from consideration. Although there is increasing interest in evaluating ecosystem-level injury from human activities (MEA 2005), many ecosystem services are difficult to directly measure and quantify. Therefore, individual indicators of injury to ecosystem services were used to create a 'weight of evidence' for ecosystem-level injury.

The conceptual models were used to develop testable hypotheses to evaluate the relationship between exposure to oil or response actions and 


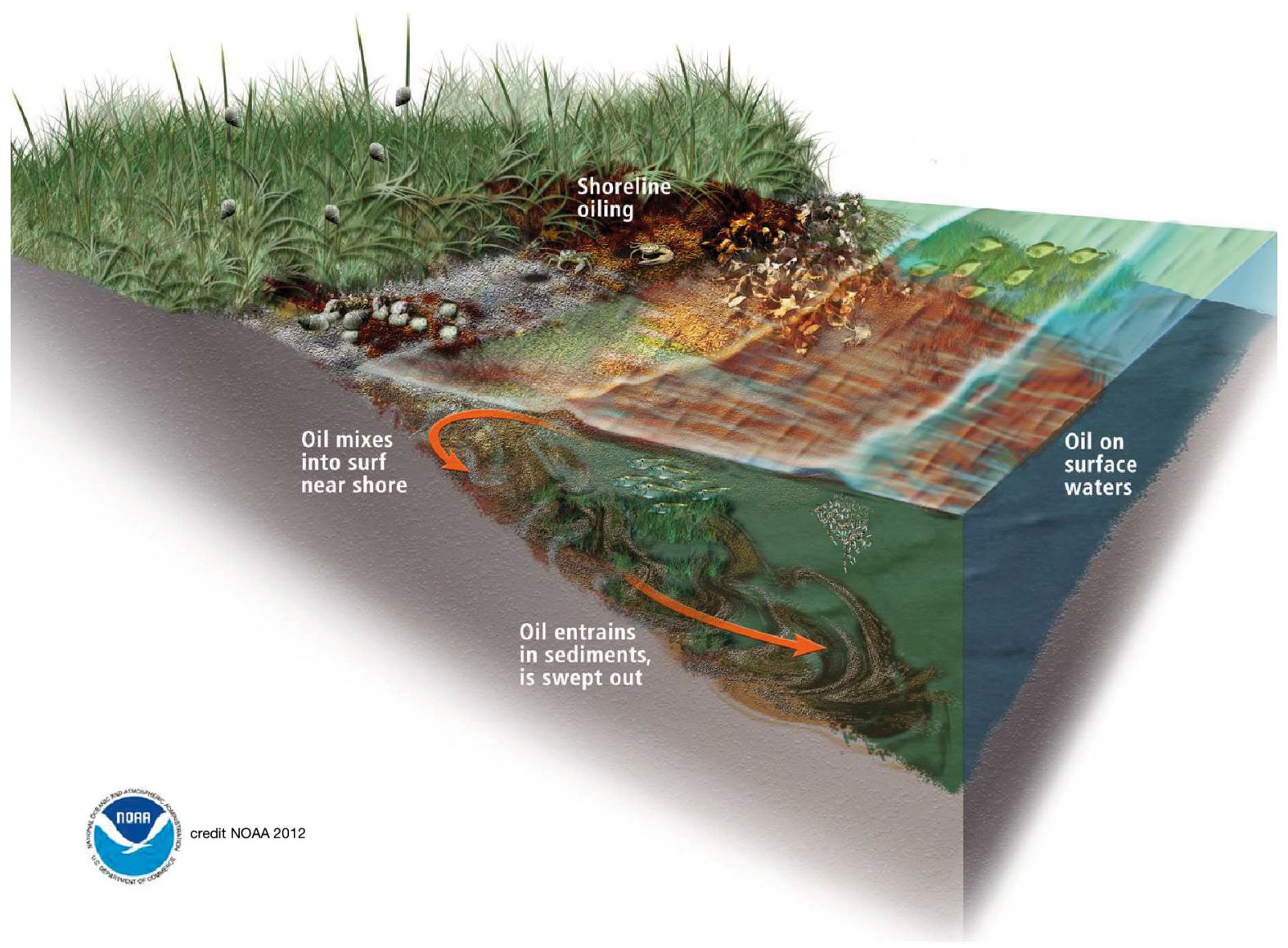

Fig. 1. Pathway for oil to reach nearshore habitats

injury metrics. For example, plant stem oiling was evaluated as the main possible driver of injury to marsh vegetation (Hester et al. 2016). Degree of shoreline oiling and associated response actions were hypothesized to be related to injury to nearshore and shoreline fauna and beach and SAV habitats (Zengel et al. 2016a, Powers \& Scyphers 2016; Kenworthy et al. 2017, Michel et al. 2017, Powers et al. 2017, all this Theme Section). Subtidal oysters were hypothesized to be affected by a combination of oiling of surface water or shoreline and exposure to river water released in an attempt to keep oil from reaching the shoreline (Powers et al. 2015).

To test the hypotheses that resulted from the development of the conceptual models, the trustees compiled evidence of exposure to oil or response actions that could result in injury to habitats and species. Exposure to oil stranded on the shore was the primary factor resulting in injury to beach and marsh habitats and associated fauna. Shoreline oiling was evaluated using a combination of linear shoreline surveys (Shoreline Cleanup Assessment Technique) conducted as part of response actions and similar linear shoreline surveys conducted by trustees in the summer of 2010. In addition, a 'preassessment' survey was conducted through the summer of 2010 to document shoreline oiling exposure and inform field sample design to quantify injury to marsh habitat (NOAA 2010). In this survey, plant stem oiling observations were gathered at targeted point locations to represent each shoreline oiling class as determined for this NRDA (see Nixon et al. 2016 for a description of oil classes). Aggregated oil on surface water was also considered as an exposure variable in evaluating injury to SAV and subtidal oyster habitats. Satellite- and aircraft-based remote sensing and aerial imagery were used to determine the number of days when surface water oiling was present in proximity to SAV and subtidal oysters (NOAA 2011).

In addition to the toxic, smothering, or fouling effects of oil, oil spill response actions also had the potential to injure nearshore habitats and species. The effects of physical disturbance such as trampling of vegetated shorelines, removal of sand and wrack from beaches, stranding of boom on shoreline habitats, building of sand berms, and the release of freshwater were evaluated. Exposure to response actions 


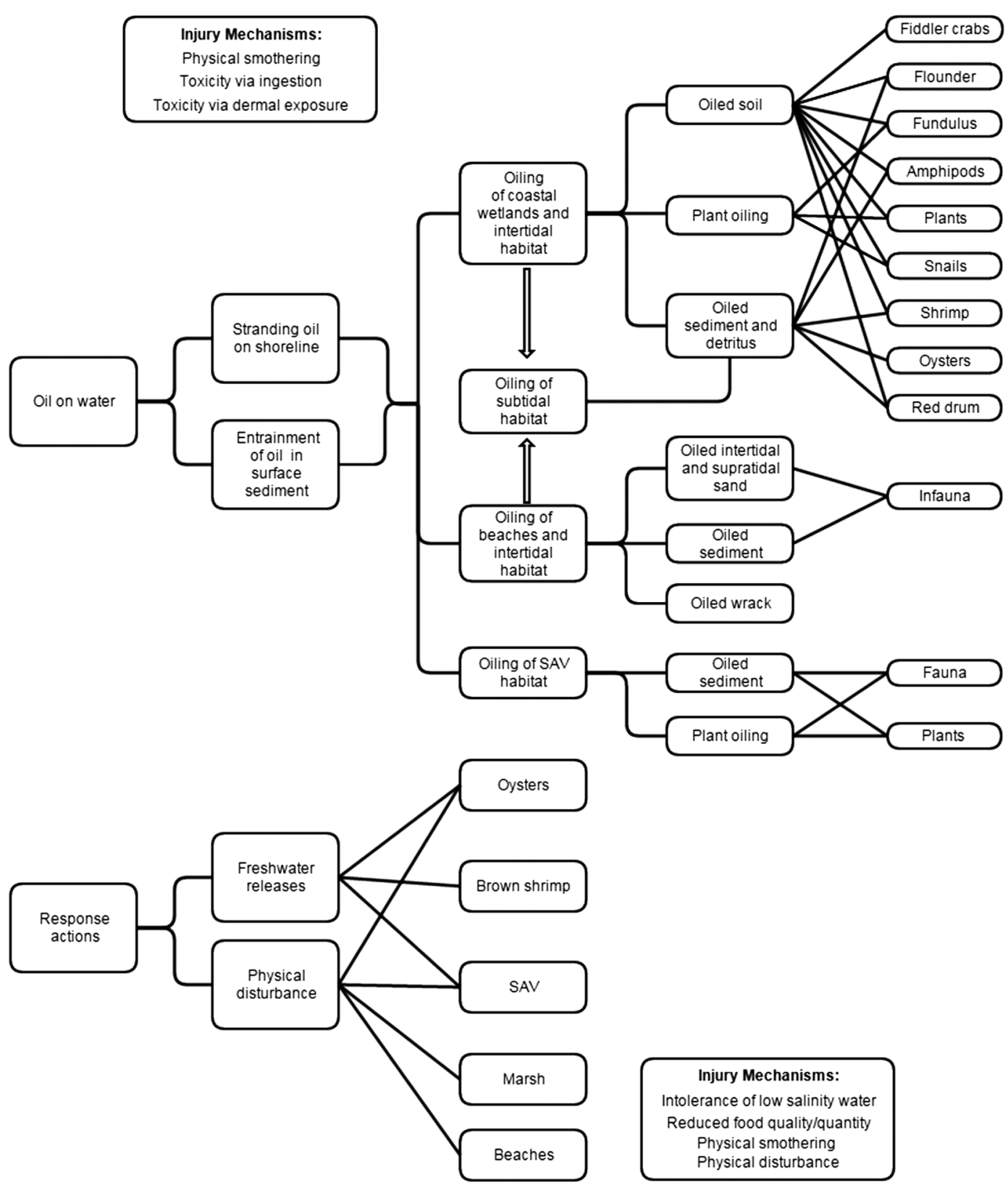

Fig. 2. Pathways of exposure for representative species to oil and response actions, and mechanisms of injury. Most resources were exposed via multiple pathways. Effects of nearshore water column exposure were considered in a separate assessment. 'Sediment' refers to submerged (intertidal or subtidal) substrates. Wetland 'soil' refers to upland or intertidal substrate colonized by vegetation. SAV: submerged aquatic vegetation

was evaluated using information on locations of boom that became stranded in marsh habitats, records of shoreline treatment on beaches and in marshes (type of treatment, timing, and location), and salinity observations in areas potentially affected by diversion of river water. Salinity observations from a variety of sources were compiled and interpolated to assist in interpreting effects on marsh fauna and nearshore and subtidal oyster abundance and recruitment (McDonald et al. 2015, Powers et al. 2015).

Injury to coastal wetland habitats was assessed by evaluating the health and productivity of vegetation and fauna, as well as erosion of the marsh edge. Coastal wetland sampling locations were selected using a stratified random design representing a range of plant stem oiling conditions (Hester et al. 2016). The design included 4 coastal wetland habitat 
types: mainland herbaceous salt marsh, back barrier salt marsh, mangrove, and the Phragmites australisdominated marshes of the Mississippi River Deltaic Plain. Injury to marsh fauna was evaluated using shoreline oiling and/or soil PAH chemistry collected at vegetation sampling sites as exposure variables (Powers \& Scyphers 2016, Zengel et al. 2016a,b, Powers et al. 2017). Individual species and life stages were selected from different trophic levels as indicators of a healthy functioning nearshore Gulf ecosystem. Known sensitivity to oil and proximity to oiled environments based on life-history information was also considered in selecting species and life stages for assessment. Marsh fauna included crabs, snails, shrimp, resident fish, burrowing infauna, and nearshore oysters that form emergent reefs or smaller hummocks that fringe marsh edges. Growth, survival, and reproduction were evaluated using a combination of field and laboratory techniques. Periwinkle snails Littoraria irrorata were studied in heavily oiled areas and sites representing reference conditions (Zengel et al. 2016a). Nearshore eastern oysters Crassostrea virginica were collected from sites representing a range of shoreline oiling and salinity conditions (Powers et al. 2017). Records on locations, methods, severity, and duration of cleanup actions compiled by the US Coast Guard and other response agencies were used to classify sampling sites as to whether they were likely to have been disturbed by response actions. Where feasible, sampling stations for different metrics were co-located so injuries could be compared and related to each other (e.g. vegetation health, shoreline erosion, and nearshore oyster cover and abundance).

Because trustees must distinguish effects associated with the incident from those caused by other environmental factors, reference site locations were randomly selected from the same habitat type and hydrologic regime as oiled sites. Coastal wetland sampling locations were selected in the late summer/early fall of 2010 and formed the basis for sampling periwinkles, fiddler crabs (Uca spp.), and nearshore oysters. Data were collected to evaluate possible confounding factors that could influence the injury metrics relating to vegetation and faunal health and marsh structure. For example, coastal Louisiana marshes have a high rate of baseline erosion due to subsidence and other factors (Glick et al. 2013). Wave exposure, duration of marsh inundation, dominant vegetation type, and hydrologic regime were considered in interpreting the influence of oiling or response actions on shoreline change and vegetation health metrics.
Injury observations for marsh habitats and associated fauna were quantified and expanded throughout the region using shoreline oiling classifications based on degree and duration of exposure (Nixon et al. 2016) and relationships with additional exposure metrics. For example, site-specific injury to plants was spatially extended across the region using the observed relationships between plant stem oiling (which was measured at each wetland injury study site) and shoreline oiling (which was characterized more broadly), weighted to account for bias in sampling designs (Nixon et al. 2015). Injury to marsh fauna (with the exception of periwinkles, which were only evaluated in one oiling category) was expanded using the relationship between observed marsh soil PAH concentrations (which were measured at each wetland injury study site) and shoreline oiling categories, also adjusted to account for sampling bias. Injury to fiddler crabs was described but not expanded to estimate the total length of shoreline injured. Estimates of the expected duration of injury to coastal wetland habitat were developed through a combination of trend analysis of field observations, and by applying information and experience from prior spills. Key datasets for determining and quantifying injury to marsh flora and fauna include coastal wetland vegetation health metrics and soil PAH concentrations measured annually from 2010 to 2013 (Hester et al. 2016; Rouhani et al. 2017, this Theme Section).

The assessment of injury to subtidal oysters $C$. virginica focused on the release of river water as part of response actions in the summer of 2010, as oysters are known to be intolerant of prolonged periods of low-salinity water (VanderKooy 2012). Exposure to oil in surface waters and on the shoreline was also evaluated. The abundance of subtidal oysters was evaluated over time at sites representing a variety of oiling and salinity influences (Powers et al. 2015). Exposure to excess freshwater was evaluated using interpolated and modeled salinity concentrations in summer 2010 (McDonald et al. 2015) and by comparing those concentrations to summer conditions during pre-spill baseline years (Rouhani \& Oehrig 2015). An area of freshwater impact was identified for oysters (Rouhani \& Oehrig 2015), and injuries were quantified using observations of oyster cover and abundance for each subregion affected (Powers et al. 2015). Estimates of the magnitude and expected duration of injury to subtidal oysters were developed by considering reproductive implications of lost spawning stock and modeled larval transport (Grabowski et al. 2015, Powers et al. 2015). 
Assessment of ecological injury to beach habitat focused on evaluating the impact of the combination of oiling and response actions. Beach injury was evaluated using shoreline oiling classifications (Nixon et al. 2016) and information on severity and duration of response actions (Michel et al. 2017). Literature and information from prior spills were used to determine relative degrees of injury which were extended over the larger region to quantify lengths and areal extent of beach habitats that were injured. Information from prior spills was also used to estimate recovery rates of beach habitats (Michel et al. 2017).

Assessment of injury to SAV focused on the intersection of oiling and/or response actions with known areas of SAV habitat. SAV habitats representing a range of shoreline oiling conditions in the Chandeleur Islands were sampled and evaluated using aerial imagery analysis to determine changes in cover between 2010 and 2012 (Kenworthy et al. 2017). Soil, sediment, and tissue samples were analyzed for PAH concentrations to evaluate exposure between 2010 and 2011 (Cosentino-Manning et al. 2015). Recovery times for SAV habitat were estimated using data from injury assessments from prior vessel groundings (Kenworthy et al. 2017).

Results from studies for each nearshore habitat and species were analyzed using various univariate statistical tests. These tests were employed to examine whether sites exposed to oil or response actions differed from reference conditions. Multivariate and exploratory methods were also used to examine relationships between variables. For all analyses, a pvalue of 0.1 was used to evaluate statistical significance of results and to balance Type I and Type II errors (Mapstone 1995). Observed effects to nearshore habitats and species were then integrated to evaluate the potential for ecosystem-wide impacts. Multiple indicators of injury evaluated for each habitat (coastal wetland, oysters, sand beaches, and SAV) were compiled by shoreline oiling categories to evaluate broader implications. These indicators were also used to determine which ecosystem services were likely affected by oiling and response actions.

\section{FINDINGS OF THE ASSESSMENT}

Injuries to nearshore resources occurred across multiple trophic levels (from plants to predatory fish) and connected habitats, including coastal wetlands, beaches, nearshore and subtidal oysters, and SAV as a result of direct oiling and response activities. Ecological functions that support the health and produc- tivity of the larger Gulf of Mexico system have been degraded, including the availability of abundant prey; stable marsh platform structure; nutrient cycling, water filtration, and clean soil and sediment that promote growth and survival of biota; healthy submersed and emergent plant cover that supports higher trophic levels and provides refuge from predators; and substrate for oyster spat settlement.

Multiple lines of evidence of an ecosystem level injury were developed through the application of interconnected conceptual models and testable hypotheses. Pathways for oil to reach nearshore habitats were identified and confirmed using observations of stranded oil, remote sensing data, and chemical analysis of stranded oil, soil, and sediment, including forensic analysis to verify the presence of oil released from the well. Analysis of this evidence verified that oil entered the nearshore environment on the surface of the water, driven by winds and currents. As it reached the shore, oil became entrained in surf as droplets or attached to particles, stranded on vegetated and beach shorelines, and redistributed to nearshore subtidal areas (Fig. 1). Over time, residual oil and components were found on plants, in beach sands and marsh soils, and incorporated into submerged sediments (Rouhani et al. 2017).

Exposure to oil released from the well occurred over a broad area and was long lasting. Each of the nearshore ecosystem habitat types in the northern Gulf of Mexico was oiled to varying degrees as a result of the spill, and the linear geographic extent of shoreline oiling was the largest of any marine spill globally (Nixon et al. 2016). Oil was observed on more than $2113 \mathrm{~km}$ (1300 miles) of shorelines from Texas to Florida. At least $965 \mathrm{~km} \mathrm{(600} \mathrm{miles)} \mathrm{of}$ beaches and $1105 \mathrm{~km}$ (687 miles) of coastal wetland shorelines were oiled (Nixon et al. 2016).

PAH concentrations were measured in soil, sediment, and biological tissues to provide additional information on exposure to oil released from the well. Soil from oiled coastal wetland habitats sampled between 2010 and 2013 contained elevated PAH concentrations when compared to unoiled shorelines, and when compared to ambient concentrations calculated using samples that were unlikely to contain DWH oil (as confirmed by forensic analysis; Rouhani et al. 2017). Concentrations of PAHs in nearshore submerged sediments were also elevated along oiled shorelines, especially within $50 \mathrm{~m}$ of shore (Rouhani et al. 2017). PAH concentrations in invertebrate tissues collected from 2011 to 2012 from beach and coastal wetland shoreline areas were variable and showed no apparent trend with the degree 
Table 1. Summary of injuries to oiled marsh vegetation and fauna. Metrics were evaluated by comparing oiled sites to un-oiled reference conditions. Regional expansion was completed using shoreline oil characterization (Nixon et al. 2016). Recovery times were estimated using field observations and information from prior spills. NC: not calculated

\begin{tabular}{|c|c|c|c|c|c|}
\hline $\begin{array}{l}\text { Model species/ } \\
\text { injury metric }\end{array}$ & $\begin{array}{l}\text { Maximum \% } \\
\text { change relative } \\
\text { to reference }\end{array}$ & $\begin{array}{l}\text { Zones } \\
\text { of } \\
\text { injury }\end{array}$ & $\begin{array}{l}\text { Km (miles) } \\
\text { of shoreline } \\
\text { affected }\end{array}$ & $\begin{array}{l}\text { Observed time } \\
\text { period } \\
\text { of injury }\end{array}$ & $\begin{array}{l}\text { Expected } \\
\text { recovery } \\
\text { time }(\mathrm{yr})\end{array}$ \\
\hline $\begin{array}{l}\text { Mainland herbaceous live above- } \\
\text { ground biomass }{ }^{\mathrm{a}}\end{array}$ & 45 & Edge, interior & $>563(>350)^{b}$ & $2010-2013$ & $2-8^{c}$ \\
\hline Mainland herbaceous total live cover ${ }^{a}$ & 44 & Edge, interior & $>563(>350)^{\mathrm{b}}$ & $2010-2013$ & $2-8^{\mathrm{c}}$ \\
\hline Amphipod survival ${ }^{\mathrm{d}}$ & 95 & Edge, interior & $249(155)$ & $2010-2013$ & $>4$ \\
\hline Periwinkle abundance $\mathrm{e}^{\mathrm{e}}$ & 90 & Edge, interior & $62(39)^{\mathrm{d}}$ & 2011 & $>10$ \\
\hline White shrimp growth (oil) ${ }^{\mathrm{d}}$ & 46 & Intertidal, edge & $288(179)$ & 2011 & $>2$ \\
\hline Brown shrimp growth (oil) ${ }^{\mathrm{d}}$ & 56 & Intertidal, edge & $288(179)$ & 2011 & $>2$ \\
\hline Fundulus hatch success ${ }^{\mathrm{d}}$ & 99 & Edge & $62(39)$ & $2010-2013$ & $>4$ \\
\hline Flounder growth ${ }^{\mathrm{d}}$ & 90 & Edge & $62(39)$ & $2011-2013$ & $>3$ \\
\hline Red drum growth ${ }^{\mathrm{d}}$ & 47 & Edge & $62(39)$ & 2010-2012 & 3 \\
\hline Fiddler crab burrow density ${ }^{\mathrm{f}}$ & 39 & Edge, interior & $\mathrm{NC}$ & 2010-2014 & $>4$ \\
\hline Nearshore oyster cover ${ }^{g}$ & 99.5 & Intertidal & $250(155)$ & $2012-2013$ & No recovery \\
\hline $\begin{array}{l}{ }^{a} \text { Hester et al. (2016), except as noted } \\
\text { b'Nixon et al. (2015) } \\
{ }^{c} \text { Michel \& Rutherford (2014) } \\
\text { dPowers \& Scyphers (2016) } \\
\text { e Zengel et al. (2016a), except as noted. } \\
\text { fZengel et al. (2016b) } \\
\text { gPowers et al. (2017, this Theme Sectio }\end{array}$ & See also Zengel e & al. $(2017$, this Th & ne Section) & & \\
\hline
\end{tabular}

of shoreline oiling (Oehrig et al. 2015). PAHs in SAV plant tissue and invertebrate whole bodies collected from SAV habitats were higher in oiled areas in August and September 2010 than in samples collected in June 2010, and declined to concentrations similar to pre-spill conditions by June 2011 (Cosentino-Manning et al. 2015). All data collected as part of the DWH NRDA are available online. ${ }^{1}$

NRDA results are generally consistent with those found in other studies after the spill, where concentrations of oil components were elevated in wetland soil (Keevan 2012, Lin \& Mendelssohn 2012, Turner et al. 2014, Atlas et al. 2015), submerged sediment (Floyd et al. 2012, Sammarco et al. 2013), nearshore surface water (Allan et al. 2012, Sammarco et al. 2013), and biological tissues (Xia et al. 2012, Sammarco et al. 2013). Two other studies did not find evidence of oil accumulation in oysters or other filter feeders after the spill (Carmichael et al. 2012, Fry \& Anderson 2014). Some oil components were observed to be elevated in marsh soils up to $3 \mathrm{yr}$ after the spill (Keevan 2012, Turner et al. 2014). Oil-

${ }^{1}$ DWH NRDA data are available at https://www.doi.gov/ deepwaterhorizon/adminrecord; https://pub-dwhdatadiver. orr.noaa.gov/dwh-ar-documents/902/DWH-AR0305139pdf; https://pub-dwhdatadiver.orr.noaa.gov/dwh-ar-documents/ 858/DWH-AR0305135.pdf degrading bacteria in marsh soils responded positively to the presence of oil (Beazley et al. 2012, Natter et al. 2012, Atlas et al. 2015).

Oiling caused multiple injuries to coastal wetland habitats, including reductions in aboveground biomass and total plant cover in mainland herbaceous salt marshes. Herbaceous salt marsh vegetation in Louisiana exposed to more than trace oiling of plant stems exhibited evidence of injury, particularly in the marsh edge zone closest to the shoreline (Hester et al. 2016). More than $1105 \mathrm{~km}$ (687 miles) of coastal wetland shoreline were reportedly oiled throughout the Gulf (Nixon et al. 2016). Injury was estimated to occur over at least $563 \mathrm{~km}$ (350 miles) of shoreline in Louisiana mainland herbaceous salt marsh alone, based on the extent of observed shoreline and plant oiling conditions (Nixon et al. 2015, 2016) and the findings of injury to oiled mainland herbaceous plants (Hester et al. 2016). NRDA findings of injury to wetland vegetation cover, photosynthesis, and biomass, particularly along the marsh edge (Table 1), were consistent with those found by other researchers (Lin \& Mendelssohn 2012, Mishra et al. 2012, Wu et al. 2012, Khanna et al. 2013, Kokaly et al. 2013, Shapiro et al. 2016). Plant stem oiling (where oiling occurred over more than $90 \%$ of the length of the stem), soil and shoreline oiling, associated response actions, and loss of nearshore oyster cover 
also affected the physical stability of vegetated shorelines, with an increased erosion rate observed between 2010 and 2013 compared to reference conditions (Gibeaut et al. 2015, Roman 2015, Silliman et al. 2016, Powers et al. 2017). Increased erosion of oiled vegetated shorelines is estimated to have occurred over at least $174 \mathrm{~km}$ (108 miles) (Powers et al. 2017). Other researchers also reported increased rates of shoreline erosion after oiling (Silliman et al. 2012, McClenachan et al. 2013, Zengel et al. 2015, Lin et al. 2016). These injuries to coastal wetland vegetation have significant implications for the overall health and productivity of the Gulf system by reducing primary production of the marsh and the stability of the marsh platform. Marsh plants form the basis of food webs and release nutrients through photosynthesis and decomposition (Peterson \& Howarth 1987). Marsh vegetation can also remove excess nutrients from runoff from upland areas (Fisher \& Acreman 2004). Marsh habitat (particularly the marsh edge, where the most severe injuries occurred) supports the productivity of open water areas by facilitating movement of animals and nutrients between emergent vegetation, intertidal, and subtidal areas for forage and refuge (Levin et al. 2001), and its degradation or permanent loss will have significant consequences for productivity of fish and wildlife.

In addition to injuries to the vegetation, all marsh faunal species evaluated in the most heavily oiled areas showed evidence of injury. Examples of observed or predicted injury include a reduction in periwinkle Littoraria irrorata abundance and recruitment (Zengel et al. 2016a; Zengel et al. 2017, this Theme Section; S. Pennings et al. unpubl.); reductions in growth (and resulting reduced survival) of shrimp (Farfantepenaeus aztecus, Litopenaeus setiferus), juvenile southern flounder Paralichthys lethostigma, and red drum Sciaenops ocellatus (Powers \& Scyphers 2016); reduced amphipod survival (Powers \& Scyphers 2016); reduced hatching success of Gulf killifish Fundulus grandis (Powers \& Scyphers 2016); reduced fiddler crab (Uca spp.) abundance (as measured by burrow density, Zengel et al. 2016b); and decreased cover of nearshore oysters Crassostrea virginica (Powers et al. 2017) (Table 1). Abundance and cover of nearshore oysters did not appear to be affected by the release of river water during response actions (Powers et al. 2017). Supporting laboratory toxicity tests indicate that the faunal effects described here could have arisen through a combination of chemical toxicity and fouling or smothering (Morris et al. 2015). Faunal injury was expanded over at least $62 \mathrm{~km}$ (39 miles) of mainland herbaceous salt marsh shoreline based on the linear extent of observed shoreline oiling where $\mathrm{PAH}$ concentrations exceeded toxic levels in laboratory studies or where injury was detected in field studies (Nixon et al. 2016, Powers \& Scyphers 2016, Rouhani et al. 2017). Bird injury was also documented; pelicans and other colonial birds nesting at 2 colonies in Barataria Bay declined by $48 \%$ between May and June, 2010, which was attributed to extensive oiling of marsh habitat (Baker et al. 2015). Non-NRDA studies also observed potential injury to Gulf killifish, benthic foraminifera, fiddler crabs, and terrestrial arthropods in oiled salt marshes (Whitehead et al. 2012, McCall \& Pennings 2012, Hatch 2013, Pennings et al. 2014).

In addition to the effects of marsh oiling on fauna, summer river water releases as part of spill response likely reduced benthic prey abundance (Adamack et al. 2012) and could have further reduced production of juvenile shrimp and other marsh fauna. Adamack et al. (2012) modeled the effects of a late April/May water release and predicted that benthic production would be 40 to $60 \%$ less than under baseline conditions. Rose et al. (2014) suggested that estuarinedependent fish and invertebrates would be displaced by river water released under an 'oil spill' scenario (similar to those that occurred after the DWH spill), but they did not quantify the effects in terms of lost production.

Injuries to marsh habitat have larger implications for the nearshore ecosystem as adverse effects to one species are likely to cascade through the food web. For example, F. grandis represent a prey item for wildlife (such as wading birds) and many sport fish, including flounder and speckled trout (Ross 2001). Some fauna play an important role in sustaining a healthy marsh. Fiddler crabs modify sediments, organic material, and nutrient cycling through their burrowing and feeding activities, affecting marsh soil communities and vegetation (Montague 1982, Hoffman et al. 1984, Gittman \& Keller 2013). Marsh periwinkle grazing plays a key role in cycling organic matter and nutrients, influencing marsh food webs and marsh plant productivity (Kemp et al. 1990, Silliman \& Zieman 2001). Marsh plants and nearshore oysters can dampen wave energy, trap and stabilize soil and adjacent sediment, and provide structure and cover for predators and prey (Zimmerman et al. 2000, Piazza et al. 2005, Mudd et al. 2010, Powers et al. 2017). Dolphins using Barataria Bay were also evaluated as part of the NRDA. Dolphins captured and evaluated in 2011 were 5 times more likely to have moderate to severe lung disease when com- 
pared to Sarasota Bay dolphins (Schwacke et al. 2014). Continued monitoring of the Barataria Bay population in 2013, 2014, and 2015 indicated that survival and reproduction were also lower than in the reference population (Lane et al. 2015). The combination of injury to vegetation, shoreline stability, and marsh fauna (Table 1) indicated that services the habitat provides to humans and other ecosystem components was likely reduced.

Subtidal oysters were evaluated separately from nearshore oysters due to their greater distance from the marsh edge. Low-salinity conditions in the summer of 2010 resulted in mortality of an estimated total of 1.2 to 3.3 billion market-sized equivalent subtidal oysters over $483 \mathrm{~km}^{2}$ in Barataria Bay and $362 \mathrm{~km}^{2}$ in Black Bay/Breton Sound, respectively (Powers et al. 2015). In contrast to nearshore oysters (which were affected by shoreline oiling), no relationship between subtidal oyster abundance and shoreline or surface water oiling could be discerned (Powers et al. 2015). The combined loss of billions of nearshore and subtidal oysters resulted in failed recruitment over several years in the most heavily impacted areas (Barataria Bay, Black Bay/Breton Sound, and Mississippi Sound), with a total estimated loss of 4.0 to 8.4 billion market-sized equivalent oysters (Grabowski et al. 2015, Powers et al. 2015). The loss of nearshore and subtidal oysters likely impaired the ecological services that oysters typically provide, including supporting a robust commercial fishery. Oysters play an important role in the nearshore ecosystem in that they filter large volumes of water, recycle nutrients, and provide forage and refuge for other invertebrates and fish (Coen et al. 2007, Grabowski \& Peterson 2007, Kellogg et al. 2013).

Injury to estuarine fish and invertebrates under surface oil slicks was assessed using a modeling approach (Travers et al. 2015). The observed extent and duration of surface slicks behind the barrier islands was calculated using synthetic aperture radar image analysis over time. Toxicity tests were conducted using slicks of weathered oil from the spill, estuarine fish embryos and larvae, and juvenile estuarine invertebrates. Based on the range of sensitivities to oil and UV light observed in these tests, the trustees estimated a total mortality of 4 to $6 \%$ of larval fish and juvenile invertebrates over an average $2.5 \mathrm{~m}$ water depth for the area and time period of slick coverage (Travers et al. 2015). As part of a nonNRDA study, Moody et al. (2013) evaluated nekton utilization of salt marsh habitats in coastal Alabama before and after the spill. Significant differences in the recruitment of nekton were not observed in 2010 and 2011 when compared to 2009 (Moody et al. 2013), but the authors recognized that other areas of the northern Gulf received more intense oiling.

Of the $965 \mathrm{~km}$ (600 miles) of beaches with observed oiling, a total of $683 \mathrm{~km} \mathrm{(424} \mathrm{miles)} \mathrm{were} \mathrm{injured}$ from oiling and disturbance from associated response actions (Michel et al. 2017). Repeated cleanup actions to remove oiled sand and wrack disrupted foraging for birds and nesting for birds and sea turtles (Cacela \& Dixon 2013, Michel et al. 2017). Based on a literature review of the effects of human disturbance to nesting birds and response records, Ritter et al. (2015) concluded that response actions would have resulted in extensive nest failure for beachnesting species over multiple nesting seasons. Because sand beaches and wrack support a variety of invertebrates that serve as important prey for migratory birds, fish, and other wildlife, physical disturbance associated with cleanup activities and oil can have serious implications for the larger system of connected habitats. Injured beaches in proximity to marsh habitats are particularly perilous for bird species that nest in dunes and feed in nearby oiled marsh habitats (Michel et al. 2017). In addition, loggerhead sea turtle Caretta caretta nest densities in northwest Florida were lower than expected in 2010 when compared to years before and after the spill. The trustees estimated that approximately 251 loggerhead nests were lost due to DWH response activities on nesting beaches (Cacela \& Dixon 2013).

SAV was injured by oiling and response actions. Chandeleur Islands seagrass was particularly affected, with more than 109 ha (270 acres) destroyed (Kenworthy et al. 2017). Chandeleur Islands seagrass habitat is unique in its extent and ecological connection to the wider Gulf of Mexico, representing one of the largest areas of seagrass beds between Pensacola Bay, Florida, and Laguna Madre, Texas (Handley et al. 2007). Seagrass meadows of the Chandeleur Islands provide forage and refuge for birds, sea turtles, and pelagic juvenile fish and invertebrates and trap and stabilize sediment (Kenworthy et al. 2017). Loss of this habitat, therefore, has broader implications for the stability of the Chandeleur Islands system, which is slowly migrating westward. Sediments deposited on the back barrier shelf are trapped and stabilized by seagrasses which help maintain the islands' elevation above sea level. The loss of seagrasses disrupts this important service and could accelerate the physical degradation of the islands (Kenworthy et al. 2017).

Injuries to SAV habitats from propeller scars generated by response vessels were documented in many 
coastal areas from the Chandeleur Islands to Apalachee Bay, Florida (Meehan 2015). Freshwater SAV habitats in Jean Lafitte National Historic Park and Preserve were altered by release of river water as part of response actions (Weston Solutions Inc. 2015). These habitats also provide important forage and refuge habitat for birds and wildlife.

Long-lasting ecosystem-level injury is particularly likely where multiple injured habitat types occur in close proximity and the most severe shoreline oiling and response actions occurred. Marsh, oyster, and beach habitats injured by a combination of oil, physical response actions, and releases of river water occur in close proximity in Barataria Bay, Black Bay/Breton Sound, and Mississippi Sound. Beach, coastal wetland, and SAV habitats in the Chandeleur Islands were also injured by oiling. Unless shoreline is eroded, prior studies indicate that oiled vegetation may recover within 2 to $8 \mathrm{yr}$ based on the warmth of the Gulf of Mexico climate, the variability of Gulf shoreline oiling, and the characteristics of the spilled oil (Michel \& Rutherford 2014, Nixon et al. 2015). Injury to marsh fauna will persist until soil concentrations drop below concentrations observed to be toxic in lab studies, or until long-lived species such as periwinkles can recover their population structure, which could be more than $10 \mathrm{yr}$ in the most heavily oiled areas (Powers \& Scyphers 2016, Zengel et al. 2016a, 2017). Recovery of predators that rely upon amphipods and other sensitive species will be delayed even further. Marsh edge erosion and destruction of nearshore oyster cover will be permanent and can only be addressed through active intervention or restoration (Powers et al. 2017). Subtidal oyster recruitment may slowly recover naturally over many years, or the spill-related losses may have been so severe that active restoration will be required to initiate recovery (Grabowski et al. 2015). The largest patches of SAV, which spread slowly through rhizome growth, will also take decades to recover (Kenworthy et al. 2017). For full ecosystem recovery to occur, environmental and habitat conditions must be suitable to support normal life history functions for all species that were affected.

\section{CONSIDERATIONS FOR FUTURE SPILLS}

The assessment of injuries to nearshore habitats under the DWH NRDA illustrated the benefits of applying new methods and integrated assessment approaches. Although very large oil spills are rare, lessons from the evaluation of multiple lines of evi- dence of injury to nearshore habitats and resources will allow trustees to improve future assessments of oil spills, regardless of the size and scope.

There is increasing interest in evaluating ecosystem-level injury from pollution incidents in the context of the Millennium Ecosystem Assessment (MEA 2005). The DWH NRDA illustrates that assessing injuries to ecosystem services can be accomplished within the requirements of NRDA if ecosystem services can be clearly defined and tied to measurable or observable indicators that respond to oil exposure. Carpenter et al. (2009) recommended general principles for evaluating ecosystem services that can also be applied to NRDA, including associating study designs to specific research questions within an overarching conceptual framework; applying models that bridge observations to concepts and theories; and contrasting injuries across locales, scales, and time periods. The use of integrated conceptual models in the DWH NRDA provided a framework for evaluating injury on an ecosystem scale. To build preparedness for future spills, trustees can adapt the DWH NRDA conceptual models to appropriate locations for likely spill scenarios. Describing pathways of exposure and injury for beaches and marshes in advance would expedite implementation of studies when spills occur. Integrating the application of the models as much as possible across nearshore habitats will allow trustees to identify (and possibly quantify) injuries to the ecosystem services described by the MEA (2005): provisioning, regulating, cultural, and supporting services. These are defined by the benefits people obtain from ecosystem attributes and components. Provisioning services include food and water; regulating services include flood and disease control; cultural services provide spiritual, recreational, and cultural benefits; and supporting services include nutrient and water cycling that maintains the conditions for life on Earth (MEA 2005).

NRDA sampling needs are typically scaled based on the size and specific conditions of the spill and requirements for selecting appropriate compensation and restoration. Many small spills are assessed using minimal information (shoreline oiling observations, samples to confirm the source of the oil, and literature on likely effects). For larger and more complex spills (with DWH being an extreme example of these), evaluating species and life stages intimately associated with shoreline oiling and that represent multiple feeding guilds and trophic levels allows trustees to integrate indicators of habitat injury with greater certainty. In the DWH NRDA, assessing multiple species and life stages found in oiled coastal 
wetland habitats illustrated larger ecosystem implications of injury. Co-locating sampling stations for assessment of soil chemistry, nearshore sediment chemistry, vegetation health, shoreline erosion, and marsh fauna abundance over transects from upland to subtidal environments maximizes the ability to compare and connect multiple injuries and scale and plan restoration to compensate for losses. For example, in the DWH NRDA, co-locating nearshore oysters with marsh vegetation injury sampling locations revealed service losses (indicated by marsh erosion) that would not otherwise have been apparent. Timing of studies is also important. For example, if bioaccumulation of PAHs and food web exposure is a concern, tissue samples from organisms with limited capacity to metabolize these compounds should be collected as soon as possible after shoreline oiling occurs.

Large, complex, or contentious spills often require multiple lines of evidence from a combination of field observations, laboratory studies, and literature findings in order to satisfy NRDA requirements to connect pathways, exposure, and injuries. For example, in the DWH NRDA, combining field studies of periwinkle Littoraria irrorata abundance in oiled areas with laboratory studies to evaluate periwinkle survival and behavior after oiling provided compelling evidence of a causal link between exposure and injury (Garner et al. 2015, Zengel et al. 2016a). Innovative field and laboratory methods for evaluating sensitive endpoints were developed and applied to NRDAs for the DWH and other recent spills. For example, as part of the NRDA for the 2007 Cosco Busan oil spill in San Francisco Bay, California, caged herring Clupea pallasii eggs were deployed in the field to examine abnormalities associated with proximity to oiled shorelines (Incardona et al. 2012). After the DWH spill, short-term growth was measured in juvenile shrimp (Farfantepenaeus aztecus, Litopenaeus setiferus) caged adjacent to oiled shorelines. That study evaluated combined pathways of exposure, including nearshore sediment and associated prey and runoff of oil, oiled soil particles, and detritus from adjacent marsh surfaces (Rozas et al. 2014). This field-based design provided a more realistic evaluation of the implications of shoreline oiling than a lab study that only exposed animals to contaminated sediment. Caged animal approaches should be further expanded to develop methods for additional species and regions. For the DWH NRDA, conducting laboratory toxicity testing of sediment spiked with weathered oil over the gradient of PAH concentrations observed in field samples allowed for com- parison of injury metrics across species and across the region using a standardized approach. These techniques could be further developed to evaluate sensitive sub-lethal endpoints for fish and invertebrates exposed to oil. After the DWH spill, high-resolution aerial imagery proved useful in evaluating shoreline erosion in Barataria Bay and changes in Chandeleur Islands SAV cover over time. In the future, it may be possible to gather appropriate imagery using unmanned aircraft systems with less time and expense.

NRDA regulations also require trustees to evaluate injury to natural resources in comparison to baseline conditions. Because pre-spill data on target organism abundance and injury endpoints for fish and invertebrates are so infrequently available, the selection of reference sites is especially important in relating injury to exposure, as is the implementation of a robust stratified random sampling design. As applied in the DWH NRDA, the selection of reference sites and collection of supporting data should account for possible confounding factors such as wave exposure, dominant plant cover (habitat type), hydrologic regime, and inundation (including the magnitude, frequency, and duration of inundation). In this spill, the loss of edge stations due to erosion reduced the ability to observe differences between oiled and reference sites over time. Baseline erosion rates should be considered at future spills when conducting power analysis to determine sampling requirements to test hypotheses. To determine whether PAH concentrations are elevated at oiled sites when pre-spill data are not available, it is possible to derive ambient concentrations after the spill using forensic chemistry data to identify samples not influenced by the spill. These concentrations may vary considerably by subregion depending on proximity to other sources (Rouhani et al. 2017).

There are several common approaches trustees use to meet the requirement of the NRDA regulations to quantify injury and translate injury metrics into restoration. Habitat equivalency analysis (HEA, Dunford et al. 2004) and resource equivalency analysis (REA, Snyder \& Desvousges 2013) equate injured ecosystem services or resources with services or resources provided by restoration projects. HEA and REA are most commonly used in NRDA when restoration techniques are available that will directly replace lost services or resources. Value-tocost approaches are less frequently used, but can identify restoration needed to compensate for lost services when requirements for HEA or REA are not met. In these techniques (e.g. contingent valuation, 
Portney 1994), the monetary value of injuries (and/or services lost) is equated to the cost of restoration to compensate for the injuries (lost services). In all of these approaches, ecosystem services affected by the spill, and the ecosystem service benefits available through restoration, should be clearly understood and articulated.

In conducting NRDAs, trustees typically simplify ecosystem services to those supporting primary and secondary production. By collecting broad and consistent information on shoreline oiling and additional exposure data at point-locations (such as plant stem oiling and soil PAH concentrations) using a statistically robust stratified random design, injuries observed at specific locations can be expanded to estimate effects over a larger area, as demonstrated in the DWH NRDA. These observations can be quantified in terms of numbers or biomass of individual resources lost (as in REA) or ecological services over a certain area or shoreline length (as in HEA). Individual metrics that may be affected by oil (e.g. marsh vegetation cover) can be associated with multiple ecosystem services (e.g. supporting, provisioning, and regulating), yet trustees can only claim compensation for the same injury once. Trustees must also account for baseline conditions and confounding factors that influence the ecosystem service being assessed.

Quantifying and valuing ecosystem services are challenging, partly because methods for analyzing and valuing many ecological functions and ecosystem services have not yet been developed (Carpenter et al. 2009). An individual ecosystem service may be provided through the combined influence of many specific resource components. For example, shoreline stability after the DWH spill was influenced by vegetation cover, above- and below-ground biomass, nearshore oyster structure, and geomorphology. The more services that are potentially affected by a spill, the more complex the assessment will be. No assessment, however, can fully examine and evaluate all ecosystem services. To support evaluation of broader ecosystem services as part of NRDAs, techniques are needed to demonstrate how physical and chemical processes affect habitat structure and ecological function, and ultimately, how they contribute services over a larger area.

Finally, as demonstrated by the DWH NRDA, coordinating NRDA with spill response activities can result in efficiencies and benefits to both groups. Shoreline oiling observations collected as part of spill response actions provided initial information for evaluating exposure to nearshore habitats and species, as well as consistent information to support expansion of injury across the region. While conducted to support cleanup decisions, these surveys provided broad spatial coverage and a consistent set of data. A combination of response data and additional data collected during early shoreline assessments (e.g. average plant stem oiling in each shoreline segment) facilitated selection of sampling strata that represented exposure conditions likely to be associated with injury to marsh vegetation and fauna (including selection of un-oiled reference sites). Although it is not required to distinguish between injury from oil and injury from response actions (since both are compensable under NRDA regulations), gathering appropriate information on response actions helps interpret observed effects and address possible confounding factors. Coordination between response and NRDA activities can improve response to future spills, since NRDA assessment findings can illustrate ecological trade-offs of shoreline and offshore response actions.

Based upon observations of the DWH NRDA, Peterson et al. (2012) provided a number of recommendations to improve NRDA, especially for spills associated with deepwater well blowouts. They correctly identified many constraints on NRDA associated with provisions of OPA, including the requirement to rely on well-established scientific approaches, the requirement to collaborate closely with responsible parties, and a focus on restoration of resources of high known value to the public. Program funding limitations and the OPA definition of restoration (replacing, restoring, or acquiring the equivalent of injured natural resources) limit opportunities for research not directly tied to quantifying injury and planning restoration for specific spills (Peterson et al. 2012). The disturbance associated with some cleanup actions on marsh and beach shorelines may have exacerbated or prolonged ecological injury and recovery. However, for the DWH spill, trustees were able to determine and quantify injuries from response actions (especially the effect of river diversions on oysters and impacts from beach cleanup activities). It is unclear whether the use of dispersants resulted in less cohesive surface water oiling and less intense shoreline oiling, as theorized by Peterson et al. (2012). Although it may not be possible to determine the influence of the use of dispersants on the extent and magnitude of shoreline oiling during this spill, contrasting the scope and magnitude of shoreline injury with predictions of mortality to early life stage fish and invertebrates in surface waters provides a basis for 
evaluating some of the benefits and drawbacks of dispersant use, and additional research and analysis of the trade-offs would further inform future spill response and damage assessment priorities.

\section{CONCLUSIONS}

For the DWH NRDA, shoreline oiling characterization proved a useful indicator of exposure for nearshore organisms. Injury was observed in all oiled nearshore habitat types examined, including coastal wetlands, beaches, SAV, and oyster reef areas. Multiple pathways and multiple mechanisms of impact were apparent, including chemical toxicity, smothering/physical fouling, physical disturbance, and intolerance of excess freshwater (low salinity).

Injury was quantified in Louisiana mainland herbaceous marshes that received even a trace amount of shoreline oiling. Both plant stem oiling and soil oiling were associated with injury, which included loss of plant cover; reductions in above-ground biomass; reduced abundance and/or growth of periwinkle snails Littoraria irrorata, fiddler crabs, shrimp (Farfantepenaeus aztecus, Litopenaeus setiferus), fish (Paralichthys lethostigma, Fundulus grandis, Sciaenops ocellatus), and nearshore oysters Crassostrea virginica; and accelerated erosion of marsh edge habitat. It was not possible to separate effects of oiling from effects of response actions in all instances. It is likely that freshwater releases also reduced production of benthic invertebrates and their predators. The marsh edge, which is the most productive zone in many respects and provides transient faunal access to flooded marsh surfaces for refuge and foraging (Zimmerman et al. 2000), was the most severely oiled and most severely injured. Because these areas promote rapid growth of juvenile fish and invertebrates of commercial importance and are also used by numerous bird species, other wildlife, larger finfish and crabs, and coastal dolphins, loss and degradation of this habitat will have broader implications for the ecosystem. Marsh recovery is expected to take more than $10 \mathrm{yr}$ for long-lived species such as periwinkles (Zengel et al. 2016a), while eroded shoreline has been permanently lost (Silliman et al. 2016, Powers et al. 2017).

Hundreds of kilometers of beaches were injured by oil and response actions. Billions of subtidal oysters perished due to the release of river water as part of response actions, and oyster recruitment was affected over a large area. SAV habitats in the Chandeleur Islands have also been degraded, and natural recovery of the largest patches of seagrass is likely to require more than $20 \mathrm{yr}$.

Ecosystem services affected by the spill include supporting services such as primary production and provisioning services such as fish and shellfish abundance. Although not directly measured, regulating services associated with stable marsh environments, such as coastal storm and flood protection, may also have been disrupted by the increased shoreline erosion associated with the spill. The loss of billions of oysters will reduce nutrient cycling and water filtration services.

The approaches and methods used in the DWH NRDA will improve the ability of trustees to evaluate integrated ecosystem impacts of oil spills of any size. Advances and innovations included the broad and integrated use of:

- unified conceptual models to understand pathways for oil and response actions to reach and injure nearshore habitats;

- soil PAH concentration measurements, forensic evaluations of soil and sediment PAH patterns, toxicity tests to determine lethal and sublethal PAH concentrations to resident species, field evaluations of vegetation health, marsh faunal abundance, shoreline change, and nearshore oysters at the same locations over time;

- evaluation of oyster recruitment success over a broader region through time; and

- high-resolution aerial imagery to evaluate shoreline change and SAV cover.

Trustees can improve future oil-spill NRDA efforts by planning ahead to develop general conceptual models to support assessment of marsh, beach, SAV, and oyster habitats. Integrating assessments using co-located transects and similar approaches and endpoints across habitats will assist in evaluating larger-scale ecosystem-level injuries. Developing clear, testable hypotheses using shoreline oiling characterization as an exposure framework for nearshore species and habitats (when combined with data on plant oiling and PAH concentrations in soils and sediments) will allow conclusions of individual studies to be extended to broader areas of oiled shorelines. A combination of field studies and laboratory toxicity testing can help elucidate relationships between exposure and injury. New and expanded techniques are needed, as are methods for evaluating additional ecosystem services within the constraints and requirements of NRDA. Integrating NRDA and response actions and further exploration of response option trade-offs will benefit both efforts. 
Acknowledgements. We thank Matt Baumann for reviews and suggestions on draft versions of this manuscript and Sean Powers for his constructive comments that greatly improved this manuscript. The findings and conclusions in this paper are those of the authors and do not necessarily represent the view of NOAA or of any other natural resource trustee for the BP/DWH NRDA.

\section{LITERATURE CITED}

Adamack AT, Stow CA, Mason DM, Rozas LP, Minello TJ (2012) Predicting the effects of freshwater diversions on juvenile brown shrimp growth and production: a Bayesian-based approach. Mar Ecol Prog Ser 444:155-173

Allan SE, Smith BW, Anderson KA (2012) Impact of the Deepwater Horizon oil spill on bioavailable polycyclic aromatic hydrocarbons in Gulf of Mexico coastal waters. Environ Sci Technol 46:2033-2039

Atlas RM, Stoeckel DM, Faith SA, Minard-Smith A (2015) Oil biodegradation and oil-degrading microbial populations in marsh sediments impacted by oil from the Deepwater Horizon well blowout. Environ Sci Technol 49: 8356-8366

Baker DT, Huisenga M, Wallace B (2015) Evaluation of potential exposures and injuries to colonial birds in coastal Louisiana caused by the 2010 Deepwater Horizon oil spill. Tech Rep. https://pub-dwhdatadiver.orr.noaa. gov/dwh-ar-documents/788/DWH-AR0293621.pdf

*Beazley MJ, Martinez RJ, Rajan S, Powell J and others (2012) Microbial community analysis of a coastal salt marsh affected by the Deepwater Horizon oil spill. PLOS ONE 7:e41305

Cacela D, Dixon P (2013) A statistical analysis of loggerhead turtle (Caretta caretta) nesting rates in western Florida (1997-2012). US Fish and Wildlife Service Tech Rep. https://pub-dwhdatadiver.orr.noaa.gov/dwh-ar-documents/ 894/DWH-AR0096905.pdf

Carmichael RH, Jones AL, Patterson HK, Walton WC and others (2012) Assimilation of oil-derived elements by oysters due to the Deepwater Horizon oil spill. Environ Sci Technol 46:12787-12795

Carpenter SR, Mooney HA, Agard J, Capistrano D and others (2009) Science for managing ecosystem services: beyond the Millennium Ecosystem Assessment. Proc Natl Acad Sci USA 106:1305-1312

* Coen LD, Brumbaugh RD, Bushek D, Grizzle R and others (2007) Ecosystem services related to oyster restoration. Mar Ecol Prog Ser 341:303-307

Cosentino-Manning N, Kenworthy WJ, Handley L, Wild M, Rouhani S, Spell R (2015) Submerged aquatic vegetation exposure to Deepwater Horizon Spill. Tech Rep. https:// www.fws.gov/doiddata/dwh-ar-documents/919/DWHAR0270744.pdf

* Dunford RW, Ginn TC, Desvousges WH (2004) The use of habitat equivalency analysis in natural resource damage assessments. Ecol Econ 48:49-70

Fisher J, Acreman MC (2004) Wetland nutrient removal: a review of the evidence. Hydrol Earth Syst Sci 8:673-685

Floyd EL, Lungu CT, Gohlke JM (2012) An evaluation of nearshore sediment data after the Deepwater Horizon blowout. J Environ Sci Eng A 1:341-350

Fry B, Anderson LC (2014) Minimal incorporation of Deepwater Horizon oil by estuarine filter feeders. Mar Pollut Bull 80:282-287
Garner TR, Hart MA, Morris JM, Stoeckel JA, Roberts AP (2015) Effects of Deepwater Horizon oil on migration and survival of marsh periwinkle snails (Littoraria irrorata). In: Proc $36^{\text {th }}$ Annual Meeting of the Society of Environmental Toxicology and Chemistry, Salt Lake City, UT. http://slc.setac.org/wp-content/uploads/2015/09/SETACSLC-Abstract-Book.pdf

*Gibeaut JC, Nixon Z, Rouhani S (2015) Shoreline change analysis of oiled and treated shorelines in Upper Barataria Bay. Tech Rep. https://pub-dwhdatadiver.orr. noaa.gov/dwh-ar-documents/901/DWH-AR0270436.pdf

* Gittman RK, Keller DA (2013) Fiddler crabs facilitate Spartina alterniflora growth, mitigating periwinkle overgrazing of marsh habitat. Ecology 94:2709-2718

Glick P, Clough J, Polaczyk A, Couvillion B, Nunley B (2013) Potential effects of sea-level rise on coastal wetlands in Southeastern Louisiana. J Coast Res (Spec Issue 63): 211-233

Grabowski JH, Peterson CH (2007) Restoring oyster reefs to recovery ecosystem services. In: Cuddington $\mathrm{K}$, Byers JE, Wilson WG, Hastings A (eds) Ecosystem engineers, plants to protists. Elsevier Academic Press, Burlington, MA, p 281-298

Grabowski JH, Marrison H, Murray J, Roman H, Rouhani S, Powers SP (2015) Oyster recruitment failure in the Northern Gulf of Mexico as a consequence of the 2010 Deepwater Horizon Oil Spill. Tech Memo. https://pubdwhdatadiver.orr.noaa.gov/dwh-ar-documents/857/DWHAR0293683.pdf

*Handley L, Altsman D, DeMay R (eds) (2007) Seagrass status and trends in the northern Gulf of Mexico: 19402002. U.S. Geological Survey Scientific Investigations Report 2006-5287 and US Environmental Protection Agency 855-R-04-003. http://pubs.usgs.gov/sir/2006/5287/ pdf/CoverandContents.pdf

Hatch RS (2013) Distribution and impacts of petroleum hydrocarbons in Louisiana tidal marsh sediments following the Deepwater Horizon oil spill. MSc thesis, University of Kentucky, Lexington, KY

Hester MW, Willis J, Rouhani S, Steinhoff M, Baker M (2016) Impacts of the Deepwater Horizon oil spill on the salt marsh vegetation of Louisiana. Environ Pollut 216:361-370

*Hoffman JA, Katz J, Bertness MD (1984) Fiddler crab deposit-feeding and meiofaunal abundance in salt marsh habitats. J Exp Mar Biol Ecol 82:161-174

* Incardona JP, Vines CA, Anulacion BF, Baldwin DH and others (2012) Unexpectedly high mortality in Pacific herring embryos exposed to the 2007 Cosco Busan oil spill in San Francisco Bay. Proc Natl Acad Sci USA 109:E51-E58

Keevan JP (2012) Assessing transformation of trace metals and crude oil in Mississippi and Louisiana coastal wetlands in response to the Deepwater Horizon oil spill. MSc thesis, Auburn University, Auburn, AL

Kellogg ML, Cornwell JC, Owens MS, Paynter KT (2013) Denitrification and nutrient assimilation on a restored oyster reef. Mar Ecol Prog Ser 480:1-19

Kemp PF, Newell SY, Hopkinson CS (1990) Importance of grazing on the salt-marsh grass Spartina alterniflora to nitrogen turnover in a macrofaunal consumer, Littorina irrorata, and to decomposition of standing-dead Spartina. Mar Biol 104:311-319

Kenworthy WJ, Cosentino-Manning N, Handley L, Wild M, Rouhani S (2017) Seagrass response following exposure to Deepwater Horizon oil in the Chandeleur Islands, Louisiana (USA). Mar Ecol Prog Ser 576:145-161 
Khanna S, Santos MJ, Ustin SL, Koltunov A, Kokaly RF, Roberts DA (2013) Detection of salt marsh vegetation stress and recovery after the Deepwater Horizon oil spill in Barataria Bay, Gulf of Mexico using AVIRIS data. PLOS ONE 8:e78989

Kokaly RF, Couvillion BR, Holloway JM, Roberts DA and others (2013) Spectroscopic remote sensing of the distribution and persistence of oil from the Deepwater Horizon oil spill in Barataria Bay marshes. Remote Sens Environ 129:210-230

Lane SM, Smith CR, Mitchell J, Balmer BC and others (2015) Reproductive outcome and survival of common bottlenose dolphins sampled in Barataria Bay, Louisiana, USA, following the Deepwater Horizon oil spill. Proc R Soc Lond B Biol Sci 282:20151944

Levin LA, Boesch DF, Covich A, Dahm C and others (2001) The function of marine critical transition zones and the importance of sediment biodiversity. Ecosystems 4: 430-451

Lin Q, Mendelssohn IA (2012) Impacts and recovery of the Deepwater Horizon oil spill on vegetation structure and function of coastal salt marshes in the Northern Gulf of Mexico. Environ Sci Technol 46:3737-3743

Lin Q, Mendelssohn IA, Graham SA, Hou A, Fleeger JW, Deis DR (2016) Response of salt marshes to oiling from the Deepwater Horizon spill: implications for plant growth, soil surface-erosion, and shoreline stability. Sci Total Environ 557-558:369-377

Mapstone BD (1995) Scalable decision rules for environmental impact studies: effect size, Type I, and Type II errors. Ecol Appl 5:401-410

McCall BD, Pennings SC (2012) Disturbance and recovery of salt marsh arthropod communities following BP Deepwater Horizon oil spill. PLOS ONE 7:e32735

* McClenachan G, Turner RE, Tweed AW (2013) Effects of oil on the rate and trajectory of Louisiana marsh shoreline erosion. Environ Res Lett 8:044030

McDonald T, Telander A, Marcy P, Oehrig J, Geggel A, Roman H, Powers S (2015) Temperature and salinity estimation in estuaries of the northern Gulf of Mexico. NOAA Tech Rep. https://pub-dwhdatadiver.orr.noaa. gov/dwh-ar-documents/863/DWH-AR0270936.pdf

Meehan S (2015) MC252/Deepwater Horizon quantification of physical response injury to submerged aquatic vegetation. NOAA Tech Rep. https://pub-dwhdatadiver.orr. noaa.gov/dwh-ar-documents/919/DWH-AR0270519.pdf

* Michel J, Rutherford N (2014) Impacts, recovery rates, and treatment options for spilled oil in marshes. Mar Pollut Bull 82:19-25

*Michel J, Fegley SR, Dahlin JA, Wood C (2017) Oil spill response-related injuries on sand beaches: when shoreline treatment extends the impacts beyond the oil. Mar Ecol Prog Ser 576:203-218

Millennium Ecosystem Assessment (2005) Ecosystems and human well-being: synthesis. Island Press, Washington, DC

Mishra DR, Cho HJ, Ghosh S, Fox A and others (2012) Postspill state of the marsh: remote estimation of the ecological impact of the Gulf of Mexico oil spill on Louisiana salt marshes. Remote Sens Environ 118:176-185

Montague CL (1982) The influence of fiddler crab burrows and burrowing on metabolic processes in salt marsh sediments. In: Kennedy VS (ed) Estuarine comparisons. Academic Press, New York, NY, p 283-301

Moody RM, Cebrian J, Heck KL (2013) Interannual recruit- ment dynamics for resident and transient marsh species: evidence for a lack of impact by the Macondo oil spill. PLOS ONE 8:e58376

Morris JM, Krasnec MO, Carney MW, Forth HP and others (2015) Deepwater Horizon oil spill natural resource damage assessment comprehensive toxicity testing program: overview, methods, and results. NOAA Tech Rep. https:// pub-dwhdatadiver.orr.noaa.gov/dwh-ar-documents/952/ DWH-AR0293761.pdf

Mudd SM, D'Alpaos A, Morris JT (2010) How does vegetation affect sedimentation on tidal marshes? Investigating particle capture and hydrodynamic controls on biologically mediated sedimentation. J Geophys Res 115: F03029

Natter M, Keevan J, Wang Y, Keimowitz AR, Okeke BC, Son A, Lee MK (2012) Level and degradation of Deepwater Horizon spilled oil in coastal marsh sediments and pore water. Environ Sci Technol 46:5744-5755

Nixon Z, Rouhani S, Oehrig J, Zhang M (2015) Plant oiling exposure and injury quantification for Louisiana mainland herbaceous saltmarsh. NOAA Tech Memo. https:// pub-dwhdatadiver.orr.noaa.gov/dwh-ar-documents/ 857/DWH-AR0270415.pdf

*Nixon Z, Zengel S, Baker M, Steinhoff M, Fricano G, Rouhani S, Michel J (2016) Shoreline oiling from the Deepwater Horizon oil spill. Mar Pollut Bull 107:170-178

*NOAA (National Oceanic and Atmospheric Administration) (2010) Deepwater Horizon/MC252/BP shoreline/ vegetation NRDA pre-assessment data collection plan, July 12, 2010. www.gulfspillrestoration.noaa.gov/ wp-content/uploads/2010/10/2010_07_30_SHORELINE_ Pre-Assessment_Plan-REDACTED.pdf

NOAA (2011) Mississippi Canyon 252/Deepwater Horizon scope of work for emergency restoration project: response impacts to seagrasses within Alabama, Florida, Louisiana, and Mississippi coastal waters. https://pubdwhdatadiver.orr.noaa.gov/dwh-ar-documents/990/DWHAR0231444.pdf

* Oehrig J, Rouhani S, Zhang M (2015) Summary of Deepwater Horizon trustees NRDA nearshore tissue tPAH concentrations. NOAA Tech Memo. https://pubdwhdatadiver.orr.noaa.gov/dwh-ar-documents/869/DWHAR0270639.pdf

* Pennings SC, McCall BD, Hooper-Bui L (2014) Effects of oil spills on terrestrial arthropods in coastal wetlands. Bioscience 64:789-795

Peterson BJ, Howarth RW (1987) Sulfur, carbon, and nitrogen isotopes used to trace organic matter flow in the saltmarsh estuaries of Sapelo Island, Georgia. Limnol Oceanogr 32:1195-1213

* Peterson CH, Anderson SS, Cherr GN, Ambrose RF and others (2012) A tale of two spills: novel science and policy implications of an emerging new spill model. Bioscience 62:461-469

* Piazza BP, Banks PD, La Peyre MK (2005) The potential for created oyster shell reefs as a sustainable shoreline protection strategy in Louisiana. Restor Ecol 13:499-506

* Portney PR (1994) The contingent valuation debate: why economists should care. J Econ Perspect 8:3-17

Powers SP, Scyphers SB (2016) Estimating injury to nearshore fauna resulting from the Deepwater Horizon Oil Spill. Tech Rep. https://www.fws.gov/doiddata/dwh-ardocuments/913/DWH-AR0301453.pdf

Powers SP, Grabowski JH, Roman H, Geggel A, Rouhani S, Oehrig J, Baker M (2015) Consequences of large scale 
hydrographic alteration during the Deepwater Horizon Oil spill on subtidal oyster populations. Tech Rep. https://www.fws.gov/doiddata/dwh-ar-documents/863/ DWH-AR0270347.pdf

Powers SP, Rouhani S, Baker MC, Roman H and others (2017) Ecosystem services are lost when facilitation between two ecosystem engineers is compromised by oil. Mar Ecol Prog Ser 576:189-202

Ritter K, Stein J, Wallace J, Carney M (2015) Impact of Deepwater Horizon oil spill response activities on sand beaches: literature review-based evaluation of injury to beach-nesting birds. Tech Rep. https://pub-dwhdatadiver. orr.noaa.gov/dwh-ar-documents/788/DWH-AR0124513. pdf

Roman HR (2015) Development of oyster nearshore injury quantification. Tech Rep. https://www.fws.gov/doiddata/ dwh-ar-documents/863/DWH-AR0270340.pdf

Rose KA, Huang H, Justic D, de Mutsert K (2014) Simulating fish movement responses to and potential salinity stress from large-scale river diversions. Mar Coast Fish 6:43-61

Ross ST (2001) The inland fishes of Mississippi. University Press of Mississippi, Jackson, MS

Rouhani S, Oehrig J (2015) Methodology used to determine the spatial extent of fresh water impact in Barataria Bay and Black/Bay Breton Sound basins in 2010. Tech Rep. https://www.fws.gov/doiddata/dwh-ar-documents/901/ DWH-AR0270373.pdf

Rouhani S, Baker MC, Steinhoff M, Zhang M and others (2017) Nearshore exposure to Deepwater Horizon oil. Mar Ecol Prog Ser 576:111-124

Rozas LP, Minello TJ, Miles MS (2014) Effect of Deepwater Horizon oil on growth rates of juvenile penaeid shrimps. Estuar Coasts 37:1403-1414

Sammarco PW, Kolian SR, Warby RAF, Bouldin JL, Subra WA, Porter SA (2013) Distribution and concentrations of petroleum hydrocarbons associated with the BP/Deepwater Horizon oil spill, Gulf of Mexico. Mar Pollut Bull 73:129-143

Schwacke LH, Smith CR, Townsend FI, Wells RS and others (2014) Health of common bottlenose dolphins (Tursiops truncatus) in Barataria Bay, Louisiana, following the Deepwater Horizon oil spill. Environ Sci Technol 48: 93-103

Shapiro K, Khanna S, Ustin SL (2016) Vegetation impact and recovery from oil-induced stress on three ecologically distinct wetland sites in the Gulf of Mexico. J Mar Sci Eng 4:33

Silliman BR, Zieman JC (2001) Top-down control of Spartina alterniflora production by periwinkle grazing in a Virginia salt marsh. Ecology 82:2830-2845

Silliman BR, van de Koppel J, McCoy MW, Diller J and others (2012) Degradation and resilience in Louisiana salt marshes after the BP-Deepwater Horizon oil spill. Proc Natl Acad Sci USA 109:11234-11239

Silliman BR, Dixon PM, Wobus C, He Q and others (2016) Thresholds in marsh resilience to the Deepwater Horizon oil spill. Sci Rep 6:32520

Snyder JP, Desvousges WH (2013) Habitat and resource

Editorial responsibility: Sean Powers (Guest Editor), Mobile, Alabama, USA equivalency analyses in resource compensation and restoration decision making. Nat Res Env 28:1-5

KTravers C, Wobus C, Morris J, Lay C, Rissing M, Forth H, Holmes J (2015) Mortality estimates of invertebrates and early life stage fish and other injury metrics in the upper mixed layer of the water column during the Deepwater Horizon oil spill. Tech Rep. https://pub-dwhdatadiver. orr.noaa.gov/dwh-ar-documents/925/DWH-AR0285143. pdf

* Turner RE, Overton EB, Meyer BM, Miles MS, Hooper-Bui L (2014) Changes in the concentration and relative abundance of alkanes and PAHs from the Deepwater Horizon oiling of coastal marshes. Mar Pollut Bull 86:291-297

VanderKooy S (ed) (2012) The oyster fishery of the Gulf of Mexico, United States: a regional management plan2012 revision. Gulf State Marine Fisheries Commission, Ocean Springs, MS. www.gsmfc.org/publications/GSMFC \%20Number\%20202.pdf

Weston Solutions Inc. (2015) Deepwater Horizon/Mississippi Canyon 252 oil spill report on submerged aquatic vegetation residing in Jean Lafitte National Historic Park and Preserve: natural resource damage assessment fall 2012 final report. Tech Rep. https://pub-dwhdatadiver. orr.noaa.gov/dwh-ar-documents/921/DWH-AR0173683. pdf

Whitehead A, Dubansky B, Bodinier C, Garcia TI and others (2012) Genomic and physiological footprint of the Deepwater Horizon oil spill on resident marsh fishes. Proc Natl Acad Sci USA 109:20298-20302

*Wu W, Biber PD, Peterson MS, Gong C (2012) Modeling photosynthesis of Spartina alterniflora (smooth cordgrass) impacted by the Deepwater Horizon oil spill using Bayesian inference. Environ Res Lett 7:045302

Xia K, Hagood G, Childers C, Atkins J and others (2012) Polycyclic aromatic hydrocarbons (PAHs) in Mississippi seafood from areas affected by the Deepwater Horizon oil spill. Environ Sci Technol 46:5310-5318

Zengel S, Bernik BM, Rutherford N Nixon Z, Michel J (2015) Heavily oiled salt marsh following the Deepwater Horizon oil spill, ecological comparisons of shoreline cleanup treatments and recovery. PLOS ONE 10:e0132324

* Zengel S, Montague CL, Pennings SC, Powers SP and others (2016a) Impacts of the Deepwater Horizon oil spill on salt marsh periwinkles (Littoraria irrorata). Environ Sci Technol 50:643-652

Z Zengel S, Pennings SC, Silliman B, Montague C and others (2016b) Deepwater Horizon oil spill impacts on salt marsh fiddler crabs (Uca spp.). Estuar Coasts 39: 1154-1163

Zengel S, Weaver J, Pennings SC, Silliman B and others (2017) Five years of Deepwater Horizon oil spill effects on marsh periwinkles Littoraria irrorata. Mar Ecol Prog Ser 576:135-144

Zimmerman RJ, Minello TJ, Rozas LP (2000) Salt marsh linkages to productivity of penaeid shrimps and blue crabs in the northern Gulf of Mexico. In: Weinstein MP, Kreeger DA (eds) Concepts and controversies in tidal marsh ecology. Kluwer, New York, NY, p 293-314

Submitted: April 21, 2016; Accepted: October 2, 2016 Proofs received from author(s): December 6, 2016 